Journal Indonesian Language Education and Literature Vol. 3, No. 1, Desember 2017

http://www.syekhnurjati.ac.id/jurnal/index.php/jeill/

\title{
PEMBELAJARAN APRESIASI CERITA RAKYAT BERMEDIA WAYANG KANCIL
}

\author{
Edy Suryanto dan Budi Waluyo \\ Universitas Sebelas Maret Surakarta, Indonesia \\ edy.kelik_uns@yahoo.co.id
}

\begin{abstract}
Abstrak
Penelitian ini bertujuan untuk: (1) menganalisis kebutuhan pendidikan karakter dalam pembelajaran apresiasi cerita rakyat; (2) mengkaji nilai-nilai cerita rakyat sebagai materi ajar; dan (3) membuat prototipe model pendidikan karakter dalam pembelajaran apresiasi cerita rakyat. Penelitian deskriptif kualitatif tahun I ini menggunakan pendekatan R \& D, yang dilaksanakan di 15 sekolah dasar mulai Mei-Oktober 2015. Subjek penelitian adalah siswa kelas V, guru kelas, dan pengambil kebijakan. Penentuan sampel secara stratified random sampling. Tempat dan peristiwa, informan, cerita rakyat, dan dokumen sebagai sumber data. Teknik pengumpulan data melalui observasi, wawancara, dan analisis dokumen. Analisis data menggunakan teknik analisis interaktif. Hasil penelitian: (1) analisis kebutuhan diidentifikasi atas: visi misi sekolah belum menjadi panduan budaya kerja; permasalahan siswa di kelas dipengaruhi kegiatan pembelajaran guru; pendidikan karakter dipengaruhi faktor pembinaan, keteladanan, model, dan pembiasaan; (2) materi ajar disusun berdasarkan tingkat keterbacaan dan daya pikir siswa; dan (3) model didesain melalui tahap pengorganisasian nilai-nilai, pengondisian pembelajaran, internalisasi nilai-nilai, dan pengembangan nilai-nilai. Pembelajaran apresiasi cerita rakyat menggunakan media wayang kancil sangat menarik dan menyenangkan sebagai model pendidikan karakter di sekolah dasar.
\end{abstract}

Kata kunci: pendidikan karakter, nilai sastra, cerita rakyat, wayang kancil, materi ajar

\begin{abstract}
This study aims: (1) analyzing the character education needs in learning the appreciation of folklore; (2) examine the folklore values as teaching materials; and (3) create a prototype character education model in learning the appreciation of folklore. This qualitative descriptive research in the first year is using $\mathrm{R} \& \mathrm{D}$ approach, which is implemented in 15 elementary schools from May to October 2015. Research subjects are the students of class V, classroom teachers, and policy makers. Determination of sample by stratified random sampling. Places and events, informants, folklore, and documents as a source of data. Data collection techniques through observation, interviews, and document analysis. Data analysis using interactive analysis techniques. Result of the research: (1) needs analysis identified on: vision of school mission not yet become guide of work culture; students' problems in the classroom are influenced by teacher learning activities; character education is influenced by coaching factors, modeling, modeling and habituation; (2) teaching materials are prepared based on the students' legibility and thinking level; and (3) models are designed through the stages of organizing values, conditioning learning, internalizing values, and developing values. learning the appreciation of folklore using Kancil wayang media is very interesting and fun as a model of character education in elementary school.
\end{abstract}

Keywords: character education, literary value, folklore, puppet deer, teaching materials 


\section{Journal Indonesian Language Education and Literature Vol. 3, No. 1, Desember 2017 \\ http://www.syekhnurjati.ac.id/jurnal/index.php/jeill/}

\section{A. Pendahuluan}

Pendidikan karakter di sekolah bukan sekadar pendidikan hafalan tentang nilainilai semata, tetapi sebagai upaya pembentukan kepribadian peserta didik yang tangguh. Hal itu agar peserta didik mampu menjadi life-long learners untuk hidup di era global dan mampu berperan positif sebagai pribadi, anggota keluarga, dan warga masyarakat. Pelaksanaan pendidikan karakter di sekolah bersumber pada nilai-nilai yang terdapat pada agama, Pancasila, budaya, dan tujuan pendidikan nasional (Kemendiknas, 2010). Melalui sumber tersebut dapat diidentifikasi nilai religius, jujur, toleransi, disiplin, kerja keras, kreatif, rasa ingin tahu, mandiri, demokratis, cinta tanah air, semangat kebangsaan, menghargai prestasi, komunikatif, cinta damai, gemar membaca, peduli lingkungan, peduli sosial, dan tanggung jawab. Nilai-nilai tersebut berkontribusi positif terhadap pembentukan karakter peserta didik. Namun, kenyataan di sekolah masih kita temukan sikap dan perilaku mereka belum mencerminkan nilai-nilai tersebut.

Hasil penelitian Zuchdi, Kunprasetya, dan Masruri (2013) merekomendasikan bahwa model pendidikan karakter dengan menggunakan pendekatan komprehensif hendaknya diintegrasikan dalam pembelajaran yang melibatkan pada semua mata pelajaran dan pengembangan budaya di sekolah. Metode dan strategi yang digunakan dalam pembelajaran bervariasi, termasuk metode enkulturasi, keteladanan, fasilitasi nilai, dan pengembangan soft skills. Selain itu, pengaruh teman sebaya, guru, orang tua, public figur, media informasi, lingkungan tidak dapat diabaikan perannya dalam pembentukan sikap, perilaku, dan kepribadian anak.

Handoyo (2012) mengungkapkan kendala pendidikan karakter di sekolah: (1) nilai-nilai karakter yang dikembangkan belum dijabarkan dalam indikator pembelajaran dengan tepat sehingga sulit diukur ketercapaiannya; (2) sekolah belum dapat memilih nilai-nilai karakter yang sesuai visi misi. Akibatnya, sekolah dalam melakukan gerakan pembangunan karakter belum terarah dan terfokus sehingga tindakan monitoring dan penilaian juga menjadi tidak jelas; (3) banyak guru belum memahami konsep pendidikan karakter yang diprogramkan pemerintah melalui pembelajaran secara menyeluruh; (4) kekurangmampuan guru menggali nilai karakter melalui mata pelajaran yang diampu sehingga tidak dapat memilih nilai-nilai penting yang dikembangkan dalam pembelajaran; (5) minimnya pelatihan guru dalam mengintegrasikan nilai-nilai 


\section{Journal Indonesian Language Education and Literature Vol. 3, No. 1, Desember 2017 \\ http://www.syekhnurjati.ac.id/jurnal/index.php/jeill/}

karakter pada mata pelajaran yang diampu sehingga kompetensi yang dimiliki terbatas; dan (6) guru belum dapat mewujudkan nilai karakter khusus sesuai karakter mata pelajaran maupun nilai karakter umum yang menjadi visi misi sekolah sehingga belum menjadi teladan atas nilai-nilai karakter yang dipilihnya.

Seseorang dikatakan berkarakter jika telah berhasil menyerap hal baik dari nilai dan keyakinan yang dikehendaki masyarakat serta digunakan sebagai kekuatan moral dalam hidupnya. Jadi, moral menjadi dasar pertimbangan bagi seseorang berperilaku. Menurut Mumpuniarti (2012), setiap orang berperilaku dalam merespons situasi dan kondisi sosial yang mencerminkan sifat menetap. Sifat itu tampak melalui pengekspresian perilaku yang mencirikan karakter orang tersebut.

Apabila pendidikan karakter dapat diintegrasikan pada semua mata pelajaran, maka strategi membermaknakan pendidikan karakter di sekolah dapat dilakukan melalui pembelajaran apresiasi cerita rakyat. Apresiasi ini dilakukan dengan cara memilih dan menggali nilai-nilai cerita rakyat yang sudah akrab dalam kehidupan anak. Nilai-nilai cerita tersebut kemudian dikembangkan, dieksplisitkan, dan dikaitkan dengan konteks kehidupan anak. Melalui cara ini diharapkan penanaman nilai-nilai yang tersublimasikan dalam cerita tidak hanya menjangkau tataran kognitif, tetapi dapat menyentuh pula tataran internalisasi atau afektif dan tataran praktik atau psikomotorik, yaitu berupa penerapan dalam kehidupan peserta didik di sekolah, keluarga, dan masyarakat.

Setiap daerah di Indonesia kaya akan cerita rakyat dan sudah dikenal akrab anggota masyarakatnya. Bagi masyarakat Surakarta tidak asing lagi bila dihadapkan dengan cerita-cerita, seperti: Dewi Sri, Jaka Tarub, Legenda Rawa Pening, Timun Emas, Rara Mendut, Jaka Kendhil, Legenda Gunung Wurung, Aji Saka, Ki Ageng Pandanaran, Legenda Kawah Si Kidang. Dalam penelitian Sulistyorini (2003) terungkap bahwa dalam cerita rakyat ternyata mempunyai nilai-nilai luhur yang perlu dilestarikan. Cerita rakyat sebagai bagian dari folklore memuat sejumlah informasi tentang sistem budaya, seperti: filosofi, nilai, norma, dan perilaku masyarakat. Cerita rakyat mengandung nilai-nilai luhur bangsa, terutama nilai karakter dan ajaran moral yang mencakupi seluruh persoalan hidup dan kehidupan.

Di lain pihak, cerita-cerita rakyat yang berkembang di masyarakat juga masih sangat menarik dan tidak kalah nilainya bila dibandingkan dengan cerita-cerita dari luar 


\section{Journal Indonesian Language Education and Literature Vol. 3, No. 1, Desember 2017 http://www.syekhnurjati.ac.id/jurnal/index.php/jeill/}

negeri. Kemenarikannya tidak hanya ditunjukkan oleh isi cerita saja, tetapi cara penuturannya juga dapat dipadukan dengan menggunakan media wayang. Cara ini dilakukan untuk mendekatkan peserta didik agar mencintai wayang sebagai salah satu hasil budaya bangsa. Penggunaan media wayang beraneka ragam dan bentuk dimungkinkan penyajian ceritanya makin atraktif dan lebih menarik.

Wayang kancil sebagai salah satu jenis media wayang yang isi dan tokoh ceritanya sudah diselaraskan dengan dinamika zaman. Wayang kancil adalah wayang yang dibuat dari kertas karton dengan menggunakan tokoh-tokoh binatang atau manusia. Dipilihnya wayang sebagai media bercerita karena perangkat tersebut bagian dari hasil budaya di lingkungan anak yang masih hidup dan perlu dipelihara kelestariannya.

\section{B. Metode Penelitian}

Penelitian ini menggunakan pendekatan R \& D yang dilaksanakan dengan langkah-langkah yang dipadatkan. Langkah penelitian pada tahun I berupa studi eksplorasi, yang bertujuan untuk mengetahui pokok masalah dan menyiapkan materi ajar cerita rakyat, serta mendesain prototipe model. Penelitian dilakukan di 15 SD Surakarta yang meliputi 5 kecamatan, yaitu: (1) Laweyan, (2) Jebres, (3) Pasar Kliwon, (4) Serengan, dan (5) Banjarsari. Alasan pemilihan tempat: (1) belum pernah dilakukan penelitian sejenis, (2) mewakili sekolah di setiap kecamatan, dan (3) bukan sekolah percontohan pendidikan karakter. Penelitian ini dilaksanakan bulan Mei-Oktober 2015.

Subjek penelitian adalah siswa kelas V, guru kelas, dan pengambil kebijakan. Penentuan sekolah di setiap kecamatan dilakukan secara stratified random sampling dengan prosedur mengambil 3 sekolah secara acak berdasarkan strata. Sumber data penelitian ini adalah tempat dan peristiwa, informan, cerita rakyat, dan dokumen. Sikap dan perilaku siswa diamati dalam pembelajaran apresiasi cerita rakyat dengan menggunakan media wayang kancil.

Teknik pengumpulan data melalui observasi, wawancara, dan analisis dokumen. Observasi dilakukan dengan cara mengamati penerapan model pendidikan karakter di kelas. Wawancara tidak terstruktur dilakukan dengan kepala sekolah, guru kelas dan guru nonkelas, siswa sampel dan siswa nonsampel, serta karyawan sekolah. Analisis dokumen untuk mengumpulkan data yang bersumber dari kurikulum atau silabus, bahan 


\section{Journal Indonesian Language Education and Literature Vol. 3, No. 1, Desember 2017 http://www.syekhnurjati.ac.id/jurnal/index.php/jeill/}

ajar, prestasi akademik, catatan sikap dan perilaku siswa, yang bertujuan untuk melengkapi hasil observasi dan wawancara. Analisis data menggunakan teknik analisis interaktif yang meliputi tahap reduksi data, penyajian data, dan penarikan simpulan (Miles dan Huberman, 1992). Uji validitas data dengan cara triangulasi (Moleong, 2007), yang mencakupi triangulasi metode, triangulasi sumber, pengecekan anggota, dan ketekunan pengamatan.

\section{Hasil dan Pembahasan}

Analisis kebutuhan didasarkan pada tiga hal. Pertama, visi misi sekolah merupakan sesuatu yang dapat menjadi sumber energi bagi setiap warga untuk merealisasikan tujuan secara bersama. Thompson dan Stricland (2001: 15) menjelaskan bahwa visi merupakan sesuatu yang menjadi tujuan organisasi dalam jangka panjang, sedangkan misi merupakan pemaparan tujuan dan sasaran yang ingin dicapai oleh organisasi. Kepala sekolah sebagai pimpinan organisasi sangat berperan untuk mengejawantahkan visi misi ke dalam kegiatan konkret yang ditujukan kepada para guru, siswa, dan petugas sekolah lainnya.

Visi misi sekolah disusun secara hierarkis dan bersifat buttom-up. Sekolah diberi otonomi mengembangkan visi misi sesuai potensi masing-masing, tetapi penjabarannya diharapkan tidak boleh keluar dari rumusan visi misi institusi di atasnya. Rumusan visi misi di setiap sekolah kecenderungan tidak sama, namun visinya sesuai visi payung, yaitu: "Terwujudnya masyarakat Surakarta beriman dan bertaqwa, cerdas, sehat, berprestasi, dan berbudaya". Misi berpayung pada kata kunci misi Dinas Pendidikan Kota maupun Dinas Pendidikan Kecamatan, seperti: bertaqwa, cerdas, bertanggung jawab, tertib, disiplin, bekerja sama, kreatif, inovatif, terampil dan produktif, jujur, rukun, tidak putus asa, sopan santun, berakhlak mulia, demokratis, berkepribadian, berdaya tahan, dan mampu memfilter budaya asing. Kata kunci menjadi ciri misi pembinaan karakter di sekolah, contoh: "Mewujudkan keteladanan guru dalam bersikap, berperilaku, dan berpikir", "Membentuk sumber daya manusia aktif, kreatif, dan inovatif", dan "Menumbuhkan kebiasaan salam, sapa, senyum, dan sopan santun".

Pengambil kebijakan meyakini visi misi memiliki benang merah pada upaya pendidikan karakter. Guru dapat menyisipkan pendidikan karakter kepada peserta didik melalui mata pelajaran yang diampu, memberi teladan, dan menyediakan kegiatan 


\section{Journal Indonesian Language Education and Literature Vol. 3, No. 1, Desember 2017}

http://www.syekhnurjati.ac.id/jurnal/index.php/jeill/

pengembangan diri, pembiasaan menegakkan peraturan. Contoh: pagi hari sebelum pelajaran di mulai, kepala sekolah memberi pengarahan selama 15 menit. Cara ini dinilai positif pada guru agar tidak terlambat mengajar di kelas atau hadir di sekolah. Kebiasaan memberikan pengarahan dapat menjadi bahan refleksi bagi guru untuk ditularkan kepada peserta didik selama beberapa menit sebelum dan setelah selesai pelajaran.

Hal terpenting untuk meningkatkan hasil belajar dan aktualisasi nilai-nilai yang dipadukan dalam pelajaran itu perlu dikembangkan ke dalam kultur sekolah yang positif. Selain itu, keikutsertaan peserta didik dalam ekstra kurikuler hendaknya diarahkan ke pengembangan kemampuan, rasa tanggung jawab sosial, potensi, dan prestasi. Dalam memadukan sejumlah mata pelajaran hendaknya dibangun melalui keterkaitan antara tujuan, isi, keterampilan, dan sikap.

Kedua, kegiatan pembelajaran di kelas diamati pada permasalahan guru dan siswa. Permasalahan guru dan siswa tidak berdiri sendiri, tetapi keduanya saling mempengaruhi. Permasalahan guru sebagai akibat dapat menyebabkan munculnya permasalahan siswa. Atau sebaliknya, permasalahan siswa dapat menimbulkan masalah pada guru. Karena guru manajer dan sutradara pembelajaran di kelas maka penyebabnya lazim ditimpakan guru. Permasalahan guru, antara lain: (1) guru tidak membuat rencana pelaksanaan pembelajaran (RPP), mereka menggunakan RPP yang terdapat pada lembar kegiatan siswa (LKS) atau pinjam pada guru dari kecamatan lain; (2) pembelajaran di kelas kurang menarik, membosankan, dan siswa pasif karena guru sering menggunakan teknik konvensional; (3) guru terpaku pada buku paket dan LKS sehingga potensi siswa belum dapat dikembangkan secara optimal karena dibatasi oleh alokasi waktu; (4) guru banyak menekankan aspek kognitif daripada aspek afektif sehingga tujuan pembelajaran apresiasi sastra belum sepenuhnya tercapai; (5) guru belum mampu menjadi model pencerita yang baik dan menarik; (6) hubungan interpersonal dengan siswa belum optimal; (7) penananaman karakter siswa melalui pembiasaan dan keteladanan kurang diperhatikan; dan (8) guru belum memiliki cara efektif untuk mengatasi sikap dan perilaku siswa pengganggu kelas. Guru baru sebatas menegur atau memberi tugas yang terkadang tidak mengarah pada upaya pembentukan karakter siswa.

Di lain pihak, permasalahan siswa, antara lain: (1) siswa kurang tertarik dan bosan mengikuti pelajaran; (2) kadang-kadang sikap dan perilaku siswa tidak sesuai 
Journal Indonesian Language Education and Literature Vol. 3, No. 1, Desember 2017

http://www.syekhnurjati.ac.id/jurnal/index.php/jeill/

etika, seperti: berkelahi, mengejek, mencuri, berkata kasar, mengganggu teman, asyik bermain-main dengan teman, dan menyontek; (3) siswa cenderung pasif dan tidak aktifinteraktif terlibat dalam pembelajaran; (4) siswa kurang diberi kesempatan belajar berekspresi untuk melatih keberanian dan rasa percaya diri; (5) siswa sering menonjolkan sifat keakuan dan kurang berempati pada teman; (6) dalam pembelajaran, siswa kurang diberi kesempatan mengeksplorasi isi cerita melalui pemecahan masalah.

Ketiga, penanaman nilai-nilai yang baik pada siswa berusia 6-12 tahun merupakan tahapan penting bagi perkembangan pribadi anak. Hal ini menjadi landasan bagi keberhasilan perkembangan pendidikan anak selanjutnya. Agar tujuan pembelajaran dapat tercapai maka guru harus memahami karakteristik siswa, tujuan, dan arti penting belajar bagi siswa, kegiatan belajar siswa, dan menguasai psikologi pendidikan anak. Pendidikan karakter di sekolah merupakan pendidikan yang menggunakan teknik menyentuh emosi dan keterlibatan siswa langsung. Pendidikan karakter menempatkan penekanan pada pembentukan kepribadian. Tujuannya adalah agar siswa menjadi manusia yang memiliki kepedulian terhadap sesama atau orang lain dan makhluk hidup lainnya.

Pencapaian tujuan pendidikan karakter di sekolah tidak hanya dipengaruhi oleh proses pembinaan saja. Akan tetapi, faktor keteladanan, model, pembiasaan ucapan, sikap dan perilaku orang tua, teman, kepala sekolah, guru dan karyawan, penggunaan media informasi, kondisi lingkungan, dan peraturan atau tata tertib tidak dapat diabaikan perannya terhadap proses pembinaan karakter di sekolah. Faktor ini diidentifikasi atas: (1) masih terdapat ucapan, sikap, dan tindakan siswa dan guru yang tidak patut dicontoh; (2) lemahnya pengawasan dan pendampingan orang tua atau guru dalam pemanfaatan media informasi; (3) sekolah dekat lingkungan tidak nyaman, tidak aman, dan kurang mendidik, seperti jalan raya, pasar, swalayan, terminal; (4) belum ada kesadaran bersama untuk menumbuhkan lingkungan sekolah yang kondusif bagi pembudayaan pendidikan karakter; (5) pelanggaran peraturan/tata tertib tidak disertai sanksi tegas dan adil bagi pelanggar.

Pengembangan karakter itu dibangun oleh faktor keteladan dalam kegiatan pembelajaran di kelas, pembiasaan dalam bentuk pengembangan budaya, dan kegiatan keseharian di rumah dan masyarakat. Ketiga faktor itu diperoleh melalui proses internalisasi. Proses internalisasi dibutuhkan waktu untuk membentuk karakter yang 


\section{Journal Indonesian Language Education and Literature Vol. 3, No. 1, Desember 2017 http://www.syekhnurjati.ac.id/jurnal/index.php/jeill/}

sesuai dengan nilai yang ditanamkan. Kebiasaan berbuat baik tidak selalu menjamin bahwa manusia yang telah terbiasa berbuat baik tersebut sadar atau cognition menghargai pentingnya nilai karakter atau valuing. Contoh, seseorang berbuat jujur. Hal itu dilakukan karena takut untuk berbuat salah, bukan karena akan mendapatkan penghargaan dari orang lain. Karena itu, pendidikan karakter dibutuhkan domain emosi atau affection. Pendidikan karakter yang baik harus melibatkan aspek knowing the good (moral knowing), desiring the good atau loving the good (moral feeling), dan acting the good (moral action).

Nilai-nilai baik, seperti: moral, sosial, etika, pendidikan, religius perlu ditanamkan pada siswa. Saat ini, siswa SD telah mengalami pelunturan sopan-santun, kesusilaan, hati nurani, rasa kemanusiaan, saling menghargai, bahkan keagamaannya. Nilai-nilai itu berkait erat dengan pemahaman kompetensi, sikap, dan perilaku yang mencerminkan kualitas akhlak, keluhuran budi pekerti, etika, penuh penghayatan atas nilai-nilai sosial kemanusiaan, rasa syukur dilandasi dengan keimanan pada Tuhan dan ketaatan menjalankan perintah-perintah-Nya serta menjauhkan diri dari larangan-larangan-Nya. Nilai-nilai tersebut tampil berwujud kebaikan-kebaikan manusiawi yang secara ideal menghasratkan tumbuh kembangnya kemaslahatan bagi umat manusia secara luas seraya menjauhi hal-hal yang mudarat, melampaui batas, remeh-temeh, dan sia-sia.

Nilai-nilai luhur itu banyak ditemukan dalam khazanah cerita rakyat yang tersebar di semua daerah Indonesia. Di dalam cerita-cerita rakyat itu tersimpan sejumlah informasi tentang sistem budaya dan gambaran masyarakatnya yang menyangkut filosofi, nilai-nilai, norma-norma, sikap, dan perilaku-perilaku. Cerita rakyat-cerita rakyat yang sudah dikenal akrab oleh siswa SD Surakarta memiliki kedudukan dan fungsi penting bagi masyarakat pendukungnya. Dalam cerita rakyat itu memuat nilainilai personal, sosial, dan religius. Selain itu, cerita rakyat tersebut memiliki manfaat bagi kehidupan masyarakat sebagai alat pendidikan, penglipur lara, protes sosial, proyeksi keinginan terpendam.

Nilai-nilai luhur cerita rakyat dari Surakarta sangat beragam. Cerita rakyat dari daerah satu dengan daerah lain memiliki kemiripan tema, tetapi faktor pengungkapan cerita dan budaya yang melatari berbeda, maka pada akhirnya mendorong munculnya tema yang berbeda pula. Contoh: cerita Ki Ageng Pandanaran kemungkinan memiliki kemiripan tema dengan cerita rakyat dari daerah lain. Cerita ini bertemakan seorang 


\section{Journal Indonesian Language Education and Literature Vol. 3, No. 1, Desember 2017 http://www.syekhnurjati.ac.id/jurnal/index.php/jeill/}

pemimpin tidak boleh memiliki sifat sombong, congkak, dan kikir; sedangkan isinya mengungkapkan pesan bahwa seorang pemimpin harus dapat hidup sederhana dan jauh dari kemewahan agar dapat menjadi teladan bagi rakyat. Kemewahan dapat menjadikan seorang pemimpin lupa terhadap tugas-tugasnya. Hal ini menandakan bahwa contoh hasil kajian dari isi cerita rakyat sejatinya mengandung nilai-nilai luhur yang dapat dijadikan sebagai materi ajar untuk membangun karakter siswa.

Pertimbangan digunakannya cerita rakyat sebagai sumber belajar, meliputi: (1) dapat menciptakan emosi kasih sayang yang mengarah pada kebaikan, hasrat untuk melakukan perbuatan yang benar; (2) menyediakan kekayaan keteladanan akan kebaikan; (3) dapat membiasakan remaja dengan aturan moral yang perlu mereka ketahui; dan (4) dapat membantu untuk membuat pengertian kehidupan, membantu untuk menciptakan kehidupan diri sendiri sebagaimana sebuah cerita. Untuk memahami sesuatu yang terdapat di dalam cerita rakyat, siswa membutuhkan waktu dalam merefleksikan pengalamannya. Siswa dapat mengulangi membaca cerita tersebut pada bagian-bagian yang dianggapnya menyenangkan, meragukan atau bagian yang dinilainya penting. Oleh karena itu, cerita rakyat dapat membantu siswa memahami dunia mereka, membentuk sikap-sikap positif, dan menyadari hubungan yang manusiawi.

Materi cerita rakyat yang disajikan dalam Lembar Kerja Siswa (LKS) dan buku paket penting dan bukan satu-satunya acuan bagi guru dalam mengajar. Materi cerita rakyat dapat diambilkan dari media lain, seperti surat kabar dan internet yang harganya relatif murah, mudah ditemukan, isi cerita dan beragam muatan nilai. Agar penyajian cerita lebih menarik, menyenangkan, interaktif, dan atraktik dapat dipadukan dengan media lain yang sudah dikenal akrab dalam kehidupan siswa, yaitu wayang kancil. Pemilihan wayang kancil dinilai pakem permaian sangat longgar dan adaptif untuk menyampaikan cerita serta cocok dengan kehidupan dunia anak-anak.

Berdasarkan hasil kajian tersebut, cerita-cerita rakyat terpilih itu dikemas sesuai konsep materi ajar dan diidentifikasi nilai-nilai yang berwawasan pendidikan karakter. Selain itu, disajikan sejumlah pertanyaan terkait dengan pemahaman siswa tentang pendidikan karakter yang selaras dengan kandungan isi cerita. Materi ajar ini diharapkan dapat menjadi sumber bagi guru dalam pembelajaran apresiasi sastra untuk membangun karakter siswa. Materi ajar ini menyediakan bagi guru berbagai pilihan 
Journal Indonesian Language Education and Literature Vol. 3, No. 1, Desember 2017 http://www.syekhnurjati.ac.id/jurnal/index.php/jeill/

cerita rakyat dan memudahkan dalam pelaksanaan pembelajaran serta membuat pembelajaran lebih dinamis dan siswa pun dapat mempelajari nilai-nilai cerita rakyat secara sistematis.

Penanaman nilai-nilai cerita rakyat kepada siswa dilakukan seiring dengan proses penerimaan pelajaran yang menyenangkan, menarik, dan interaktif. Cara ini diharapkan dapat memudahkan siswa mentransfer nilai-nilai cerita yang disertai dengan bimbingan menirukan dan memberikan kesempatan mengembangkan sikap empati dan menganalisis nilai-nilai yang ditanamkan tersebut. Karena itu, materi ajar ini disusun sistematik melalui pemaparan: (1) petunjuk belajar bagi siswa/guru; (2) kompetensi yang akan dicapai; (3) materi pembelajaran (cerita rakyat); (4) informasi tentang identifikasi nilai-nilai cerita rakyat berwawasan pendidikan karakter; (5) pertanyaanpertanyaan yang berkait dengan materi ajar untuk mengembangkan aspek kognitif, psikomotorik, dan afektif siswa. Selanjutnya, guru/dalang melalui materi ajar ini siap menyajikan cerita rakyat dengan menggunakan media bantu wayang kancil.

Perancangan model diawali dengan penggalian data pembelajaran apresiasi cerita rakyat. Dalam pembelajaran, siswa tidak sekadar menjawab pertanyaan-pertanyaan yang terdapat di dalam cerita rakyat. Akan tetapi, siswa disodori beberapa cerita rakyat untuk dipilih bersama, kemudian diminta membaca dalam hati untuk menemukan dan mengidentifikasi nilai-nilai sebagai pijakan penghayatan, penikmatan, dan pemahaman cerita. Guru mengajak siswa menyelami kedalaman isi cerita, menikmati keindahan pilihan kata-kata, menilai kebagusan isi cerita, kemenarikan cara penceritaan, serta menyelami keagungan nilai-nilai cerita. Cara tersebut diharapkan menjadi perbendaharaan pengetahuan, pengalaman, dan keterampilan siswa untuk memperkaya wawasan esensial yang terkandung dalam cerita rakyat. Hasilnya tentu saja ada yang pantas untuk direnungpikirkan, bahkan ada yang patut diteladani sebagai proses apresiasi.

Pengembangan desain pendidikan karakter ke dalam pembelajaran apresiasi cerita rakyat dilakukan melalui beberapa tahapan. Pertama, pengorganisasian nilai-nilai cerita rakyat ke dalam RPP. Pengorganisasian berbagai nilai itu berisi kegiatan yang dilakukan oleh siswa sebagai fondasi pembentukan karakter, misal: (a) setiap mengawali jam pelajaran pertama dan mengakhiri jam pelajaran terakhir dilakukan doa bersama dipimpin guru/ketua kelas; jika terlambat dan masuk kelas harus mengetuk pintu dan 


\section{Journal Indonesian Language Education and Literature Vol. 3, No. 1, Desember 2017}

http://www.syekhnurjati.ac.id/jurnal/index.php/jeill/

mengucapkan salam; setiap mengawali pelajaran mengucapkan "selamat pagi/selamat siang"; berbaris dan berjabat tangan dengan guru ketika masuk jam pelajaran pertama dan jam terakhir mau pulang; (b) agar terjadi interaksi antarsiswa, guru merotasi tempat duduk siswa secara bergantian; (c) untuk menanamkan nilai-nilai pada siswa, guru setiap mengajar membuat tema pembelajaran; (d) guru bersama siswa melakukan refleksi tentang perwujudan nilai-nilai cerita rakyat untuk dipilih sebagai fokus pembelajaran. Perwujudan nilai-nilai cerita rakyat yang ditanamkan pada siswa, antara lain: kasih sayang, tidak senang berselisih, amanah, dapat dipercaya, ikhlas berkorban, berani melawan kejahatan, berpegang teguh pada kejujuran, kepedulian terhadap sesama, kesadaran berbakti pada orang tua, tanggung jawab, rendah hati, sopan-santun, setia, menghargai orang lain, mensyukuri nikmat Tuhan, hati-hati dan tidak ceroboh, setiap berusaha disertai doa, tidak iri hati, tidak sombong, dermawan, hidup rukun, selalu berbuat untuk kemaslahatan orang lain, kebenaran.

Kedua, pengondisian pembelajaran penggalian nilai-nilai cerita rakyat. Dalam kegiatan ini, siswa menyimak cerita yang disajikan oleh guru/dalang untuk menemukan nilai-nilai melalui penjelasan dan pertanyaan-pertanyaan yang telah disiapkan oleh guru sebelumnya. Hal ini dimaksudkan agar siswa memiliki kesadaran rasional dan tumbuh perasaan mencintai serta sikap empati terhadap orang lain, alam dan lingkungan serta makhluk Tuhan yang lain. Melalui cara ini diharapkan siswa dapat memetik hikmah cerita tentang keteladanan. Model merupakan keteladanan yang lebih mengedepankan aspek perilaku dalam tindakan nyata daripada sekadar berbicara tanpa aksi. Menyimak atau membaca sebuah cerita diharapkan dapat meningkatkan kesadaran anak tentang nilai-nilai moral, sosial, etika, pendidikan, dan religius serta permasalahan lain yang belum dipahami sebelumnya.

Ketiga, internalisasi nilai-nilai cerita rakyat ke dalam bentuk bermain peran. Kegiatan ini sebagai tindak lanjut tahap pengondisian yang dimaksudkan agar siswa mampu menerapkan nilai-nilai ke dalam perilaku nyata. Siswa akan mampu melakukan tindakan nyata sesuai dengan nilai-nilai yang sebelumnya telah tumbuh dan terbangun pengetahuan, keterampilan, dan sikap dengan baik pula. Internalisasi ini tidak langsung dapat menjadi bagian yang permanen dalam kehidupannya, akan tetapi internalisasi adalah sebuah proses. Proses internalisasi memerlukan waktu untuk membentuk karakter yang sesuai dengan nilai-nilai yang ditanamkan. Penanaman nilai pada diri 


\section{Journal Indonesian Language Education and Literature Vol. 3, No. 1, Desember 2017 http://www.syekhnurjati.ac.id/jurnal/index.php/jeill/}

anak didik dapat memberikan perubahan besar pada kehidupannya sebagai manusia. Makin dini nilai tersebut diberikan, makin baik kepribadian anak dalam kehidupannya.

Keempat, pengembangan nilai-nilai cerita dilakukan dengan cara pembiasaan pada pelajaran lain yang relevan. Pada tahap ini, guru menyesuaikan perkembangan jiwa anak, karakteristik materi pelajaran, dan lingkungan yang dihadapi. Perkembangan jiwa anak SD memiliki sifat: (a) rasa ingin tahu yang kuat dan tertarik pada dunia sekitar yang ada di dekatnya; (b) senang mengatur dirinya sendiri untuk mengatasi berbagai masalah, suka bereksplorasi terhadap lingkungan dan mencoba hal-hal yang dianggapnya baru; (c) senang bermain dan lebih memilih hal-hal menggembirakan; (d) mudah tergetar perasaannya dan terdorong berbuat lebih baik ketika mengalami ketidakpuasan dan menolak kegagalan-kegagalan; (e) belajar lebih tekun ketika dirinya merasa puas dengan situasi yang terjadi; dan (f) suka belajar dengan cara mengobservasi, berinisiatif, bekerja, dan mengajar pada teman-teman lainnya.

\section{Simpulan}

Berdasarkan analisis kebutuhan pendidikan karakter di SD se-Surakarta dapat disimpulkan bahwa visi misi sekolah masih sebatas jargon dan belum diejawantahkan ke dalam program kerja konkret. Proses penanaman nilai-nilai pada siswa merupakan tahapan penting yang dibutuhkan bagi perkembangan kepribadian anak. Oleh karena itu, teknik pembelajaran yang digunakan hendaknya menyentuh emosi dan pelibatan siswa secara langsung. Selain itu, pendidikan karakter di sekolah tidak hanya dipengaruhi oleh proses pembinaannya saja, tetapi faktor keteladanan, model, pembiasaan warga sekolah, pengawasan penggunaan media informasi, kondisi lingkungan, dan peraturan/tata tertib sekolah tidak dapat diabaikan perannya. Materi ajar pendidikan karakter berbasis apresiasi cerita rakyat diambilkan dari cerita-cerita rakyat yang sudah dikenal dalam kehidupan siswa sehari-hari. Penanaman nilai-nilai cerita itu dilakukan dengan cara yang menyenangkan, menarik, dan interaktif dengan menggunakan media wayang kancil. Penggunaan wayang kancil sebagai media bantu bercerita sebagai upaya pelestarian hasil budaya bangsa yang sudah mulai dilupakan generasi muda. 


\section{Journal Indonesian Language Education and Literature Vol. 3, No. 1, Desember 2017 \\ http://www.syekhnurjati.ac.id/jurnal/index.php/jeill/}

\section{Daftar Pustaka}

Handoyo, B. (2012). "Kendala-kendala dalam Implementasi Pendidikan Karakter di Sekolah", dalam Jurnal Pendidikan Karakter, Tahun IV, Nomor 1, Februari 2014.

Kementerian Pendidikan Nasional. (2010). Pengembangan dan Pendidikan Budaya dan Karakter Bangsa: Pedoman Sekolah. Jakarta: Kemendiknas Republik Indonesia.

Miles dan Huberman. (1992). Analisis Data Kualitatif, Buku Sumber tentang Metodemetode Baru. Jakarta: UI Press.

Moleong,L.J.X. (2007). Metodologi Penelitian Kualitatif. Bandung: PT Remaja Rosdakarya.

Mumpuniarti. (2012). "Pembelajaran Nilai Keberagaman dalam Pembentukan Karakter Siswa Sekolah Dasar Inklusi", dalam Jurnal Pendidikan Karakter Tahun II, Nomor 3, Oktober 2012, LPPMP Universitas Negeri Yogyakarta, 248-257.

Prasetya, A. dan Rivashinta, E. (2011). "Konsep Urgensi dan Implementasi Pendidikan Karakter di Sekolah”, dalam http://edukasi.kompasiana.com, 27 Mei 2011.

Sulistyorini, D. (2003). "Mitos Masyarakat terhadap Legenda di Kecamatan Boyolangu Kabupaten Tulungagung" Hasil Penelitian, Lembaga Penelitan Universitas Malang.

Thompson, A. dan Strickland, AJ. (2001). Crafting and Executing Strategy.London: McGraw Hill.

Zuchdi, D. (2006). Humanisasi Pendidikan: Menemukan Kembali Pendidikan yang Manusiawi. Jakarta: PT Bumi Aksara.

Zuchdi, D.; Kunprasetya, Z.; dan Masruri, M.S. (2013). Model Pendidikan Karakter Terintegrasi dalam Pembelajaran dan Pengembangan Kultur Sekolah. Yogyakarta: Multi Pressindo. 